\title{
XIX. On the choice of steel, and the methods of hardening and tempering it
}

\author{
Mr. S. Varley
}

To cite this article: Mr. S. Varley (1798) XIX. On the choice of steel, and the methods of hardening and tempering it, Philosophical Magazine Series 1, 2:5, 92-97, DOI: 10.1080/14786449808676887

To link to this article: http://dx.doi.org/10.1080/14786449808676887

曲 Published online: 18 May 2009.

Submit your article to this journal $\sqsubset \pi$

Џ Article views: 5

Q View related articles $\sqsubset$ 
equal, the velocity with which the hydrogen gaz enters the balloon, will not experience the leaft change. When the firt gazometer is entirely empty, the cock $Z I$ is hut, and the firft gazometer is filled; and the cock $Z \mathrm{I}$ is not opened till a little before the fecond gazometer is totally emptied. The fecond gazometer is then to be filled again, and in this manner the combuftion of hydrogen gaz may be continued hy thefe gazometers to any length of time without interruption. To introduce the oxygen gaz without interruption into the balloon by means of two gazometers, it will be fufficient that the two cocks, which form a communication between the gazometers and the balloon, be immediately fixed in the covering of the latter.

Both halves of the apparatus being fimilar, the letters of reference are only marked on that part which is given is outline upon the plate.

XIX. On the Cboice of Steel, and the Metbods of bardening and tempering it. By Mr. S. VARLEx. Communicated by tbe Autbor.

IT

$T$ feldom happens that theory and practice are united in the fame individual: the man of fcience often labours under a great difadvantage (notwithftanding his excellent theories) for want of the experience of the practitioner, and the practical man feldom has a theory to guide hin. He knows from experience that certain things or operations will produce a particular effect, but can give no reafon why. His application to bufinefs has not allowed him time to fearch into caufes, nor to reafon upon effects; and it would be difficult to perfuade this ufeful clafs of men how much theoretical knowledge might be gained by applying their leifure hours to ftudy, and how much pleafure might be derived from thus uniting theory with practice, which fo $\mathrm{mu}$ tually affit each other. 
I was led to thefe reflections by reading Mr. Collier's paper on iron and fteel (inferted in the firft number of your excellent Magazine), in which he gives fome methods of hardening and tempering fteel; and concludes by faying, that the fprings for penknives are covered over with oil before they are expofed to the fire to be tempered, but gives nis reafon for that application. I thall therefore endeavour to fupply that defect, and add fome other obfervations on the management of fteel, conceiving that any ufeful hint on a fubject fo univerfally applicable to the manufactories of this country will be of general benefit. It is a fubject of the firft importance to the practical mechanic: take this ufeful fubftance away, and he would be utterly incapable of proceeding one ftep forward, and would foon be convinced that fteel is of more value than gold itfelf.

For ordinary purpofes, the method noticed by Mr. Collier will anfwer very well, both for hardening and tempering; but in many cafes it is neceflary that the fteel nlould be of the beft quality, and be both hardened and tempered in fuch a manner as to preferve the greateft hardnefs poffible without brittlenefs; and fteel is of more or lefs value in proportion as it poffelles this property in a greater or lefs degree.

Steel, when foft, can be wrought into almoft any form as well as iron, welding excepted, of which the better forts, particularly caft fteel, are incapable. It can be forged, filed, turned in a lathe, drawn into wire, rolled into large plates, \&cc. \&c. and, when by thefe means brought into the defired form, it can then be made fo hard as to be capable of cutting the hardeft fubftances (the precious ftones excepted), while at the fame time it is alnoft proof againft being itfelf worn by friction : but in this ftate it is brittle, like all other hard fubftances, and for many purpoles mutt have this brittlenefs leffened, and this is what is termed by workmen, tempering, and confifts in giving it certain degrees of heat according to the temper defired, which may be produced in any degree until the whole effect of hardening is deftroyed, and the fteel 
is reduced to its foft ftate. On each of thefe operations I thall offer a few remarks, proved by long experience; and, firt, on the choice of feel for fuch purpofes as require the beft that can be procured for making cutting inftruments, fuch as gravers, punches, turning tools, chifels, \&c. \&c. to be employed in turning or cutting tempered fteel, and fubftances that are too hard to be cut by tools made of ordinary fteel: for thefe purpofes caft fteel is undoubtedly the beft; but even this fort differs in quality.

The general mode of choofing fuch as is moft fuitable for the above purpofes is to break a bar, and obferve its fracture, and to felect the clofeft grained; but this mode is not always certain, owing to the difference made in the fracture by the fteel being hammered under a greater or lefs degree of heat, fteel being much improved by being hammered under a low heat, and even when cold; and when overheated, being quite fpoiled for the above purpofe. It is owing to this circumftance that the beft forts of caft fteel are incapable of being welded as above mentioned. Another method is, to harden with as low a heat as poffible a piece of fteel, and then to break it, and obferve its fracture: but this is not wholly to be depended upon; for fome feel breaks with a very clofe grain, and yet is not of a good quality. But the fureft method is to have one end of a bar drawn out into a fmall rod under a low heat, an obfcure red for inftance, or but little above; then heat it as before, and fud. denly plunge it into pure cold water : if it proves hard, and requires a great force to break it, it is good, let its fracture be what it may*; and $I$ have always found that the fpecimens that hardened with the loweft heat, and when in that ftate required the greateft force to break them, proved the beft fteel. Having thus felected fteel fit for the required ufe,

* This circumstance deserves particular attention, as workmen, in general, reject such steel as breaks with a coarse fracture, even though it be of such a quality as to require a great force to breakit after being hardened. 
and, with the precautions already noticed, given it the proper form, it may be hardened; but the fame method will not anfwer for all parpoles. Some pieces, from their fize and figure, are very difficult to be hardened; if they are large, they heat the water in immediate contact with them, and the heat is commanicated to the reft of the water, fo faft that it prevents the pices from being cooled quick enough to produce the defired effect : this is in part prevented by continually moving the piece about in the water; but when too large to be hardened by this method, a fream of water mut be employed; and for fuch pieces as the face of large anvils, a birch broom is ufed with advantage to break the bubbles that are formed by the continual difengagement of air, and which, if not rwept away, would prevent that imtimate contagt and uniform fucceftion of the ftream neceffary to produce the degree of hardnefs required. Other articles, from their length, are difficult, and almoft impoffable to be made hard withont bending, or otherwife astering their figure: this circumftance occafions a great deal, of trouble; and many a piece of work is fpoiled, after a good deal of labour has been beftowed upon it. The method that has fucceeded but with me is, either to enclofe the piece or pieces intended to be hardened in an iron cafe or box, open at one end (for the more ready dropping the pieces into the water), and giring it a now, yet regular heat ; then to take the cafe out of the fire, and drop the pieces into the water in fuch manner as will allow them to come as little as poffible in contact with the air. This method anfwers two good purpofes at once, caufing the heat to be more equally applied, and preventing the contact of the air, and of courfe any fcaling; and when the work has been polifhed and well defended from the air, it comes out nearly as clean as it was before. When the greateft poffible hardnefs is required, it may be obtained by ufing quickfilver inftead of water; but this can only be employed for fmall articles. For fome purpofes fteel is required to have a fuperior degree 
of hardnefs given to its furface, fuch as in the cafe of files, \&cc. This is obtained by ufing a coarfe powder made of leather flightly burned, hair or horn, either in rafpings or in powder: this is mixed with a little common falt, and the files, when juft red hot, are thruft into a heap of this powder, fome of which adhering to their furface is carried into the fire with them, and gives them a cafe hardening: the falt fluxes upon their furface, and defends them from the air while paffing from the fire into the trough of water, into which they are plunged to harden. The workmen fay, the longer this water is ufed for this purpole the better.

We are now come to the laft procefs called tempering, for one method of which fee Mr. Collier's paper; but that method cannot be conveniently applied in all cafes, and has feveral difadvantages, fome of which I fhall mention. Firft, each piece muft be made bright that the change of colour may be better feen, and mult be heated fingly or nearly fo ; and pieces of irregular figure cannot be made to receive an equal degree of heat in all their parts, fo that fome will be fofter than others. Thefe circumitances would retard the manufactory of many articles very much, and prevent their being afforded at the prefent prices, fuch as the fprings of gun locks, door locks, various articles in clock and watch work, \&c. \&c. The necellity of making them bright enough to mark the change of colour is obviated by fmearing them with oil or tallow, which helps to apply the heat more uniformly, and marks the temper as well as by obferving the colour, or nearly fo; or by putting the things to be tempered into a proper veffel, and adding fo much oil or tallow as will cover them, and then holding them over the fire or the flame of a lamp until a fufficient heat is given. By this means the moft irregular pieces may be uniformly heated, and great numbers may be done at one time, and with great certainty: thus are clock and watch pinions, watch verges, balances, \&c. tempered; fometimes many dozens at once; and no more time is neceffary for the 
whole than would be for one fingle article. The requifite temper may be known by the following circumftances: When fuch a heat is given that the tallow is firlt obferved to fmoke, it indicates the fame temper as that called a fraw colour : this will reluce the hardnefs but little; but if the heat is continued until the fmoke becomes more abundant, and of a darker colour, it will be equal to a brown, and indicates a temper that may be wrought-that is, which may be turned or filed, but with difficulty, and only when a mild fort of fteel is employed. If the tallow be heated fo as to yield a black fmoke, and fill more abundant, this will denote a purple temper; and if the fteel is good, it will now work more pleafantly, though ftill hard enough to wear well in machinery. The next degree nay be known by the tallow taking fire if a lighted body is prefented to it, but yet not fo hot as to continue to burn when the light is withdrawn; this would equal a full blue colour. Increafe the heat till the tallow continue to burn, being once lighted, and this will denote a pale blue: and if the whole of the tallow be allowed to burn away, or to burn dry, as the workmen call it, itgives what click-makers mofly ufe for their work. Furtber tallow is ufelefs; a fmall degree of heat more would juft be feen in a dark place, or the loweft degree of a red heat : fuch is the temper given to the fprings for coaches, \&c. Thus I have given a reafon why oil or tallow is made ufe of, and given you the parallel degrees of temper which by a dry heat are obferved by the change of colour only. The method of hardening in quickfilver is of great ufe where a fuperior degree of hardnefs is required; and good fteel fo hardened, when the precautions before mentioned are duly attended to, will eut glafs like a diamond, and turn or cut other fteel at fo high a temper as to differ. but little from quite hard.-Perhaps at a future time I may give you a method by which this hardeft of fteel may alfo be worked with confiderable eafe, and the cafes in which I have applied it to advantage.

Vol. Il. 